\title{
Participation of rural women in micro credit: A study on BRAC in sadar upazila of Gazipur district
}

\author{
M. M. Rana ${ }^{1}$, M. A. Rahman ${ }^{2}$, G. M. K. Uddin ${ }^{3}$ and P. K. Sarma ${ }^{4}$ \\ ${ }^{1}$ International Fertilizer Development Corporation, Gulshan-2, Dhaka-1212, ${ }^{2}$ Department of Agricultural Finance, \\ Bangladesh Agricultural University, Mymensingh-2202, ${ }^{3}$ Poriborton Somaj Kallan Sangtha, Jhikargacha, Jessore, and \\ ${ }^{4}$ Bangladesh Agricultural University Research System, Bangladesh Agricultural University, Mymensingh-2202, \\ Bangladesh. Email: parash_so@yahoo.com
}

\begin{abstract}
The study presents the issues of rural women in Sadar Upazila of Gazipur district considering their participation in micro credit programs for poverty alleviation. Data were collected from 75 BRAC women beneficiaries of four villages following random sampling techniques. On the basis of credit, the respondent's have been classified into three categories. These are: i) A-small credit (up to Tk.4000) ii) B-Medium credit (Tk.4001-7000) and iii) C-Large credit (Tk.7001-10000). Average credits received by the respondents were Tk. 3250, Tk. 5875, and Tk. 8895 by small, medium, and large categories, respectively. The average annual income and savings of the respondents were Tk. 24245 and Tk. 1106, respectively. The repayment rate was 69.81 percent. Level of education, size of own land area, amount of income, savings and amount of loan received were found to be positive contribution to loan repayment performance. The study clearly hints that micro credit provides greater opportunity for rural poor women to improve their socioeconomic conditions.
\end{abstract}

Keywords: Rural women, Participation, Micro Credit

\section{Introduction}

Poverty consists in the lack of certain basic capabilities of the human beings-the capabilities to live a healthy active life free of avoidable morbidity and premature mortality and the capability to live with dignity with adequate clothing, shelter, etc. Programs for poverty alleviation must consider a range of quality of life variables such as nutrition, health and sanitation, housing, personal security, access to state distribution system, participation and institutional capability, crisis cropping capacity, etc. Various dimensions of poverty are by no means reducible to any single indicator of poverty.

The majorities of the world's poor are rural, and will remain so for several decades. Poverty reduction programs must therefore be refocused on rural people if they are to succeed. Poverty is not genderneutral: women enjoy less access to, and control over, land, credit, technology, education, health care and skilled work. Women now comprise the largest part of those living below the poverty lines who are some 31.5 percent of the population in Bangladesh (World Bank, 2011).

About half of the total population in Bangladesh is women. Unfortunately, they are deprived in the main stream of development and their contribution to the economy is not recognized enough. Most of the women in Bangladesh depend on men for their basic need such as food, clothing, shelter and security. Women perform different economic activities like livestock rearing, fisheries, nursery, handicraft, tailoring and petty trading programs. Lack of opportunities of the women to involve in the decision making process and income generating activities are some of the crucial problems in women empowerment, for this reason, government and non-government organizations (NGOs) implementing different projects and programs to involve women in the development process (Kabir, 2005).

Micro-credit creates a virtuous cycle to break the vicious circle of poverty. The central premise of this targeted credit approach creates self-employment with appropriate support for the borrower which helps them to employ income generating activities so that they can increase their income, savings, consumption etc., and come out from poverty. Women in Bangladesh have been benefited from such micro-credit programs demonstrated by their increased income and assets. Several impact studies (Hossain 1998; BIDS 1990; Alamgir 1998) show that micro-credit recipient households have better standard of living, improved housing, higher human development status and greater assets and have shifted away from money lenders. 
Micro credit has become the core program for many NGOs working with rural women in Bangladesh. To mitigate the high demand for micro credit from the rural women and creating the opportunity of achieving financial viability, the NGOs are encourage to introduce new micro-credit programs in a big way. Some program - based micro credit facilities have been offered to women through selected ministries. In addition, a number of NGOs have initiated micro-credit schemes for poor rural women to alleviate poverty. Many studies have been conducted on NGOs activities. They initiated some projects such as health, nutrition, family planning, education, crops, livestock and poultry, fisheries, housing credit and savings etc., for poverty alleviation. Various steps have so far been adopted and special importance for rural development is emphasized. As a part of these steps, micro-credit programs of BRAC were started in 1972. BRAC works with people whose lives are dominated by extreme poverty, illiteracy, diseases and other handicaps. With multifarious development interventions, BRAC strives to bring about positive change in the quality of life of these people. The major interventions of BRAC include organization development and micro credit, education, health and capacity building at the grass-root s level. Microcredit programs are particularly important for rural women who are excluded by social custom from working outside home. BRAC has developed a number of sectoral programs which are facilitated by its credit, training and technical support services and are implemented through the overall rural development program (RDP). So, the researchers attempted to undertake the study with the following objectives:

i) To determine the socioeconomic characteristics of the women beneficiaries in the study area;

ii) To analyze the amount of loan, utilization patterns and repayment performance of the respondents;

iii) To assess the impact of different influencing variables on the respondent's repayment performance.

\section{Materials and Methods}

Four villages namely Dakshin salana, Kathora, Dighirchala and Sharifpur under Gazipur Sadar Upazila of Gazipur district were purposively selected for this study. After selection of villages, a list of current beneficiaries (2010/2011) was collected from the BRAC branch office situated at Chandana.. A total number of 75 women loanees were selected from the villages. A random sampling technique was followed in this study. The data was collected in July 2011 and completed within 50 days. The researchers collected necessary primary data through personal interview with the individual women. Tabular analysis was done to compare with different loan categories. Multiple regression (Gujrati, 1995) analysis was used to determine the impact of different independent variables on loan repayment of the loanees which was specified as:

$$
Y=a+b_{1} x_{1}+b_{2} x_{2}+b_{3} x_{3}+b_{4} x_{4}+b_{5} x_{5}+b_{6} x_{6}+e_{i}
$$

Where,

$Y=$ Amount (Tk.) of loan repaid by the respondents

$\mathrm{X}_{1}=$ Age of the respondents, measured in years

$\mathrm{X}_{2}=$ Respondent's own land area

$\mathrm{X}_{3}=$ Respondent's education, measured by year of schooling

$\mathrm{X}_{4}=$ Respondent's income

$X_{5}=$ Respondent's savings

$\mathrm{X}_{6}=$ Amount (Tk.) of loan received from BRAC by the respondents

$\mathrm{a}=$ Constant

$\mathrm{b}=$ Regression co-efficient

$\mathrm{e}_{\mathrm{i}}=$ Error term 
Rana et al.

\section{Results and Discussion}

Family size and dependency ratio of the sample households

The average size of the selected families were found to be 5.09 for all categories and the dependency ratio was 3.03. The average family size of loan category-A was the highest among the three categories of households and average family size was decreasing with the increase in credit (Table 1).

Table 1. Average family size and dependency ratio of the beneficiaries

\begin{tabular}{|c|c|c|c|c|}
\hline Loan categories & $\begin{array}{c}\text { Average family } \\
\text { size }\end{array}$ & $\begin{array}{c}\text { Average earning } \\
\text { members }\end{array}$ & $\begin{array}{c}\text { Average dependent } \\
\text { members }\end{array}$ & $\begin{array}{c}\text { Dependency } \\
\text { ratio }\end{array}$ \\
\hline A & 5.19 & 1.50 & 3.69 & 3.46 \\
(Upto Tk. 4000) & $(100)$ & $(28.90)$ & $(71.10)$ & 2.87 \\
\hline B & 5.13 & 1.79 & 3.34 & \\
(Tk. 4001 to 7000) & $(100)$ & $(34.89)$ & $(65.11)$ & 2.66 \\
\hline C & 4.89 & 1.84 & 3.05 & 3.03 \\
\hline (Tk. 7001 to 10000) & $(100)$ & $(37.63)$ & $(62.37)$ & \\
\hline All & 5.09 & 1.68 & 4.41 & \\
\hline
\end{tabular}

Figures within the parentheses indicate percentages

Source: Field Survey, 2011

\section{Age distribution of the respondents}

Age distribution of the respondents was classified in the three groups according to loan categories:

i) Young (upto 34 years)

ii) Middle aged (Above 34 to 50 years)

iii) Old (Above 50 years)

Table 2 reveals that higher proportions (54.67 percent) of the respondents were young aged. The remaining 40.00 percent and 5.33 percent of the respondents belonged to the middle and old aged groups, respectively.

Table 2. Age distribution of the respondents

\begin{tabular}{|c|c|c|c|c|c|c|c|c|}
\hline \multirow[t]{3}{*}{ Loan categories } & \multicolumn{6}{|c|}{ Age distribution } & \multirow{2}{*}{\multicolumn{2}{|c|}{ Total }} \\
\hline & \multicolumn{2}{|c|}{$\begin{array}{c}\text { Young } \\
\text { (Up to } 34 \text { years) }\end{array}$} & \multicolumn{2}{|c|}{$\begin{array}{c}\text { Middle aged } \\
\text { (Above } 34 \text { to } 50 \\
\text { years) }\end{array}$} & \multicolumn{2}{|c|}{$\begin{array}{c}\text { Old } \\
\text { (Above } 50 \text { years) }\end{array}$} & & \\
\hline & Number & Percent & Number & Percent & Number & Percent & Number & Percent \\
\hline $\begin{array}{c}\text { A } \\
\text { (up to Tk.4000) }\end{array}$ & 17 & 53.13 & 12 & 40.62 & 2 & 6.25 & 32 & 100 \\
\hline $\begin{array}{c}\text { B } \\
\text { (Tk. } 4001 \text { to } 7000)\end{array}$ & 13 & 54.17 & 10 & 41.66 & 1 & 4.17 & 24 & 100 \\
\hline $\begin{array}{c}\text { C } \\
\text { (Tk. } 7001 \text { to 10000) }\end{array}$ & 11 & 57.90 & 07 & 36.84 & 1 & 5.26 & 19 & 100 \\
\hline All & 41 & 54.67 & 30 & 40.00 & 4 & 5.33 & 75 & 100 \\
\hline
\end{tabular}

Source: Field Survey, 2011 


\section{Annual household income of the respondents}

Overall income of the respondent households constitutes agriculture, non-agriculture and income from family members. Table 3 shows that the average annual income from all sources were estimated at Tk. 24245.28 for all loanees but loan category-C respondents average annual income was the highest Tk. 230157.20 during the study year, while maximum income were earned from non- agricultural sources.

Table 3. Average annual household income of the respondent's (in Tk.)

\begin{tabular}{|c|c|c|c|c|}
\hline \multirow{2}{*}{ Loan categories } & \multicolumn{3}{|c|}{ Sources of income } & Total income \\
& Agril. sector & Non-Agril. sector & Family sector & \\
\hline A & 5414.22 & 15180.31 & 106.41 & 20700.94 \\
(Up to Tk.4000) & $(26.16)$ & $(73.33)$ & $(0.51)$ & $(100)$ \\
\hline B & 6050.18 & 18125.40 & 115.21 & 24290.79 \\
(Tk.4001 to 7000) & $(24.91)$ & $(74.64)$ & $(0.47)$ & $(100)$ \\
\hline C & 6415.23 & 23575.65 & 166.32 & 30157.20 \\
(Tk.7001 t0 10000) & $(21.27)$ & $(78.18)$ & $(0.55)$ & $(100)$ \\
\hline All & 5871.32 & 18249.56 & 124.40 & 24245.28 \\
& $(24.22)$ & $(75.27)$ & $(0.51)$ & $(100)$ \\
\hline
\end{tabular}

Figures within the parentheses indicate percentages

Source: Field Survey, 2011

\section{Annual savings of the respondent households}

Savings of the respondents of different loan categories were calculated by deducting the corresponding total expenditure from the total income of the borrowers. Again total savings were also derived by adding surplus generated savings and compulsory savings of the respondents in BRAC society.

Table 4 shows that the average amount of annual savings of the respondents had been estimated at Tk. 1106.68 during the study year. It is apparent from the table that there was a positive relationship between loan amounts and savings.

Table 4. Annual savings of the respondents

\begin{tabular}{|c|c|c|c|c|c|}
\hline Loan categories & $\begin{array}{c}\text { Average } \\
\text { annual } \\
\text { income } \\
\text { (Tk.) }\end{array}$ & $\begin{array}{c}\text { Average } \\
\text { annual } \\
\text { expenditure } \\
\text { (Tk.) }\end{array}$ & $\begin{array}{c}\text { Surplus generated } \\
\text { savings from income } \\
\text { (Tk.) }\end{array}$ & $\begin{array}{c}\text { Compulsory savings } \\
\text { in BRAC society } \\
\text { (Tk.) }\end{array}$ & $\begin{array}{c}\text { Total } \\
\text { savings } \\
\text { (Tk.) }\end{array}$ \\
\hline $\begin{array}{c}\text { A } \\
\text { (Up to Tk.4000) }\end{array}$ & 20700.94 & 20334.16 & 366.78 & 382.16 & 784.94 \\
\hline B & 24290.79 & 23696.78 & 594.01 & 513.36 & 1107.31 \\
\hline (Tk.4001 to 7000) & C & 29173.07 & 984.13 & 724.25 & 1708.38 \\
\hline All & 24245.28 & 23649.39 & 595.89 & 510.79 & 1106.68 \\
\hline
\end{tabular}

Source: Field Survey, 2011

Amount of credit extended by BRAC during investing year was categorized into three ranges as follows: A (Up to Tk. 4000), B (Tk. 4001-7000), and C (Tk.7001-10000). Proper use of credit promotes increased production and benefits the participants involved. Use of credit for unproductive purpose very often results in loan default and weakens the financial viability of the concerned lending institution. 


\section{Amount of loan and utilization patterns of credit}

Table 5 shows that 43 percent, 23 percent and 25 percent of the sampled respondents within the range of up to Tk. 4000, Tk. 4001 to 7000 and Tk. 7001 to 10000 respectively. The average amount of the loans was Tk. $3250.00,5875.00$ and 8894.74 in category A, B and C respectively. Table 5 also shows that the maximum of loan money was utilized by the respondents for productive purposes.

\section{Table 5. Loan amount and utilization patterns of credit}

\begin{tabular}{|c|c|c|c|c|c|}
\hline Loan categories & $\begin{array}{l}\text { Number of } \\
\text { respondents }\end{array}$ & $\begin{array}{c}\text { Average } \\
\text { amount } \\
\text { received(Tk.) }\end{array}$ & $\begin{array}{c}\text { Expenditure on } \\
\text { agricultural } \\
\text { sector(Tk.) }\end{array}$ & $\begin{array}{c}\text { Expenditure on } \\
\text { non- agricultural } \\
\text { sector(Tk.) }\end{array}$ & $\begin{array}{c}\text { Family } \\
\text { expenditure } \\
\text { (Tk.) }\end{array}$ \\
\hline $\begin{array}{c}\text { A } \\
\text { (Up to Tk.4000) }\end{array}$ & $\begin{array}{c}32 \\
(43)\end{array}$ & 3250.00 & $\begin{array}{c}1170.98 \\
(36.03)\end{array}$ & $\begin{array}{l}926.90 \\
(28.52)\end{array}$ & $\begin{array}{l}1152.12 \\
(35.45)\end{array}$ \\
\hline $\begin{array}{c}\text { B } \\
\text { (Tk.4001 to 7000) }\end{array}$ & $\begin{array}{c}24 \\
(32)\end{array}$ & 5875.00 & $\begin{array}{l}2127.34 \\
(36.21)\end{array}$ & $\begin{array}{l}1834.76 \\
(31.23)\end{array}$ & $\begin{array}{l}1912.90 \\
(32.56)\end{array}$ \\
\hline $\begin{array}{c}\mathrm{C} \\
\text { (Tk.7001 to 10000) }\end{array}$ & $\begin{array}{c}19 \\
(25)\end{array}$ & 8894.74 & $\begin{array}{l}3519.56 \\
(39.57)\end{array}$ & $\begin{array}{l}3108.71 \\
(34.95)\end{array}$ & $\begin{array}{l}2266.38 \\
(25.48)\end{array}$ \\
\hline
\end{tabular}

Figures within the parentheses indicate percentages

Source: Field Survey, 2011

\section{Repayment of credit by the respondents}

Repayment capacity is one of the crucial aspects of credit analysis and proper utilization of credit is supposed to have a great influence upon the repayment capacity of the respondents. Table 6 shows that in all categories the average amount of loan due for recovery was found to be Tk. 6348 and the average amount repaid by the respondents was Tk.4431.33. Average amount repaid constituted 69.81 percent of the average amount due for the study year. It is evident from the table that repayment percentage was quite satisfactory.

Table 6. Repayment of loan by the respondents

\begin{tabular}{|c|c|c|c|c|c|c|c|}
\hline \multirow[t]{2}{*}{ Loan categories } & \multicolumn{3}{|c|}{ Average amount due } & \multicolumn{3}{|c|}{ Average amount repaid } & \multirow{2}{*}{$\begin{array}{c}\text { Percentage of } \\
\text { total } \\
\text { repayment }\end{array}$} \\
\hline & $\begin{array}{l}\text { Principal } \\
\text { (Tk.) }\end{array}$ & $\begin{array}{l}\text { Interest } \\
\text { (Tk.) }\end{array}$ & $\begin{array}{l}\text { Total } \\
\text { (Tk.) }\end{array}$ & $\begin{array}{l}\text { Principal } \\
\text { (Tk.) }\end{array}$ & $\begin{array}{l}\text { Interest } \\
\text { (Tk.) }\end{array}$ & $\begin{array}{l}\text { Total } \\
(\text { Tk.) }\end{array}$ & \\
\hline $\begin{array}{c}\text { A } \\
\text { (Up to Tk.4000) }\end{array}$ & 3250.00 & 487.50 & 3737.50 & 2343.75 & 351.56 & 2695.31 & 72.12 \\
\hline $\begin{array}{c}\mathrm{B} \\
\text { (Tk.4001 to } 7000)\end{array}$ & 5875.00 & 881.25 & 6756.25 & 4250.00 & 6.37 .50 & 4887.50 & 72.34 \\
\hline $\begin{array}{c}\mathrm{C} \\
\text { (Tk.7001 to 10000) }\end{array}$ & 8894.74 & 1334.21 & 10228.95 & 5894.74 & 884.21 & 6778.50 & 66.27 \\
\hline Average & 5520.00 & 828.00 & 6348.00 & 3853.33 & 578.00 & 4431.33 & 69.81 \\
\hline
\end{tabular}

Source: Field Survey, 2011

The estimated coefficients and related statistics of the multiple regression analysis were done to measure the impact of different influencing variables on the respondent's repayment performance, are summarized in Table 7.

Table 5 reveals that regression co-efficient of the respondent's age was found to be negative and statistically significant at 5\% level. Respondent's owned land, education, income, savings and loan received were found to be positive contribution to loan repayment performance. 
Table 7. Estimated coefficients and related statistics of the multiple linear regression analysis

\begin{tabular}{|c|c|c|c|c|}
\hline Independent variables & Constant/Co-efficient & t-value & $R^{2}$ & \\
\hline Age $(\mathrm{X} 1)$ & -14.53 & $-2.24^{\star \star}$ & & \\
\hline Owned land(X2) & 249.29 & $1.10^{\star}$ & \multirow{2}{*}{0.78} & 313.42 \\
\hline Education(X3) & 69.15 & $2.18^{\star \star}$ & \\
\hline Income $(\mathrm{X} 4)$ & 0.02 & $2.00^{\star \star}$ & & \\
\hline Savings $(\mathrm{X} 5)$ & 0.19 & $28.05^{\star}$ & & \\
\hline
\end{tabular}

*indicates significant at $1 \%$ level, **indicates significant at $5 \%$ level

\section{Conclusion}

The rural economy of Bangladesh is predominantly poor and the majority of the people live below poverty line. BRAC is the largest international level NGO which during the last three decades, has been operating in Bangladesh at the grassroots level for poverty alleviation and upliftment of the socio-economic conditions of the rural women. The participation of the rural women in credit programs are indication of demand-led patterns of the socio-economic development and poverty alleviation of the rural poor people in the country. Rural women do have adequate potential in the sense that they are able to participate in any activity within and outside that men do. They use loan in diversified activities and mostly for productive purposes. Provision of credit is an important element for involving the rural women in income generating and development activities in Bangladesh.

\section{References}

Alamgir, D.A.H. 1998. The Impact of Poverty Alleviation Programme of the PKSF: A Case Study, Unpublished Research Report, Dhaka.

BIDS. 1990. Evaluation of Poverty Alleviation Programmes in Bangladesh". Main Report, November, 1990.

Gujrati, Darnodar N. 1995. Basic Econometrics. Third edition, McGraw-Hill, Inc.

Hossain, M. 1998. Credit for Alleviation of Rural Poverty: The Experience of Grameen Bank In Bangladesh, BIDS, Dhaka.

Kabir,G.M. 2005. Rural Women In Micro-Finance Programs For Poverty Alleviation: A Comparative Socio-Economic Analysis of Jagorani Chakra and Banchte Shekha (NGOs) In Some Selected Areas Of Jessore District. The Jahangirnagar Economic Review Vol. 16, No. 1, June 2005, Jhangirnagar University, Savar, Dhaka.

World Bank. 2011. World Bank Development Report, Washington, D.C. 